\title{
Cytology of Sclerotinia sclerotiorum and Related Species
}

\author{
By J. A.-L. WONG* AND H. J. WILLETTS \\ School of Botany, University of New South Wales, Kensington, \\ New South Wales 2033, Australia
}

(Received 5 September 1978)

\begin{abstract}
Isolates of Sclerotinia sclerotiorum (Lib.) de Bary, S. trifoliorum Erikss. and S. minor Jag. were studied to determine if the numbers of nuclei in mature ascospores and chromosome numbers of these fungi could be used for identification purposes. Isolates of $S$. minor had four nuclei in each ascospore and a haploid chromosome count of four, S. trifoliorum had four nuclei in each ascospore and a haploid chromosome count of eight, and S. sclerotiorum had two nuclei per ascospore and a haploid chromosome count of eight. Thus, consistent cytological differences were observed, supporting our earlier conclusions that $S$. minor, $S$. trifoliorum and $S$. sclerotiorum are distinct species.
\end{abstract}

\section{INTRODUCTION}

For many years there has been controversy over the taxonomy of the fungi Sclerotinia sclerotiorum, S. trifoliorum and S. minor. After detailed studies of a number of morphological characteristics, Purdy (1955) suggested that these species were conspecific and grouped them into a single species, S. sclerotiorum. Recently, we have carried out electrophoretic (Wong \& Willetts, 1973, 1975b) and mycelial interaction (Wong \& Willetts, 1975a) studies on these fungi and concluded that $S$. minor, S. trifoliorum and S. sclerotiorum are distinct species. Cytological observations were not included in our earlier work but it was decided subsequently that cytological data could assist in resolving this taxonomic problem. Björling (1942, 1951) found that the numbers of nuclei in ascospores of S. sclerotiorum and $S$. trifoliorum were two and four, respectively, and that the haploid number of chromosomes of both species was six. The latter observation disagreed with the results of Frandsen (1946), who concluded that the haploid chromosome number of S. trifoliorum was eight. No cytological studies have been reported for $S$. minor. This paper describes an investigation of the numbers of nuclei in ascospores and chromosome counts on selected isolates of these species. All cultures had been identified previously by means of electrophoretic enzyme patterns.

\section{METHODS}

Nineteen isolates of Sclerotinia (six of $S$. minor, six of S. trifoliorum and seven of $S$. sclerotiorum) were studied. Details of the isolates are given in Table 1.

The isolates were grown on boiled cellophane discs placed on potato dextrose agar medium (Oxoid) in culture plates and incubated at $20^{\circ} \mathrm{C}$ under fluorescent light at an intensity of 150 to 200 lux. When vegetative mycelia had grown to appropriate stages for study, pieces of cellophane were cut from the discs, stained and examined under the microscope.

The method described by Purdy (1967) was used for the production of apothecia in the laboratory. Sclerotia of $S$. trifoliorum were incubated at $12{ }^{\circ} \mathrm{C}$ and those of the other species were incubated at $15^{\circ} \mathrm{C}$. Apothecia were obtained from most of the isolates, but attempts in the laboratory to produce apothecia from some isolates of S. trifoliorum (S6, S7, S33/1 and S76) were unsuccessful. However, ascocarps were obtained from

* Present address: New Town Research Laboratories, Department of Agriculture, New Town, Tasmania 7008, Australia. 


\section{Table 1. Isolates of Sclerotinia spp.}

\begin{tabular}{|c|c|c|c|c|}
\hline Species & $\begin{array}{c}\text { Isolate } \\
\text { no. }\end{array}$ & $\begin{array}{l}\text { Herbarium } \\
\text { no.* }\end{array}$ & $\begin{array}{c}\text { Size of } \\
\text { sclerotia } \dagger\end{array}$ & Origin + \\
\hline S. minor & $\begin{array}{l}\text { S1 } \\
\text { S2 } \\
\text { S3 } \\
\text { S4 } \\
\text { S22 } \\
\text { S77 }\end{array}$ & $\begin{array}{l}\text { ATCC } 34323 \\
\text { ATCC } 34324 \\
- \\
- \\
-\end{array}$ & $\begin{array}{l}S \\
S \\
S \\
S \\
S \\
S\end{array}$ & $\begin{array}{l}\text { Sunflower, N.S.W. } \\
\text { Tomato, N.S.W. } \\
\text { Potato, N.S.W. } \\
\text { Sunflower, N.S.W. } \\
\text { Unknown, N.S.W. } \\
\text { Lettuce, Tas. }\end{array}$ \\
\hline S. trifoliorum & $\begin{array}{l}\text { S6 } \\
\text { S7 } \\
\text { S33/1 } \\
\text { S47 } \\
\text { S48 } \\
\text { S76 }\end{array}$ & $\begin{array}{l}\text { - } \\
\text { ATCC } 34326 \\
\text { ATCC } 34327 \\
- \\
- \\
-\end{array}$ & $\begin{array}{l}\text { L } \\
\text { L } \\
\text { L } \\
\text { L } \\
\text { L } \\
\text { L }\end{array}$ & $\begin{array}{l}\text { Lucerne, N.S.W. } \\
\text { Lucerne, N.S.W. } \\
\text { White Clover, Tas. } \\
\text { Red Clover, U.K. } \\
\text { White Clover, U.K. } \\
\text { White Clover, Tas. }\end{array}$ \\
\hline S. sclerotiorum & $\begin{array}{l}\text { S8 } \\
\text { S9 } \\
\text { S10 } \\
\text { S11 }\end{array}$ & $\begin{array}{l}\text { DAR } 16935 \\
-\overline{17481} \\
\text { DAR } 17 \text { ATCC } 34325)\end{array}$ & $\begin{array}{l}\text { L } \\
\text { L } \\
\text { L } \\
\text { L }\end{array}$ & $\begin{array}{l}\text { French bean, N.S.W. } \\
\text { French bean, N.S.W. } \\
\text { Cauliflower, N.S.W. } \\
\text { Cabbage, N.S.W. }\end{array}$ \\
\hline & $\begin{array}{l}\text { S12 } \\
\text { S13 } \\
\text { S92 }\end{array}$ & $\begin{array}{l}\text { DAR } 26220 \\
\text { DAR } 26223 \\
-\end{array}$ & $\begin{array}{l}\text { L } \\
\text { L } \\
\text { L }\end{array}$ & $\begin{array}{l}\text { Sunflower, N.S.W. } \\
\text { Capsicum, N.S.W. } \\
\text { Sclerotium in soil, } \\
\text { Tas. }\end{array}$ \\
\hline
\end{tabular}

* DAR, Herbarium of the N.S.W. Department of Agriculture, Rydalmere, N.S.W., Australia; ATCC, American Type Culture Collection, Maryland, U.S.A.

$\dagger \mathrm{S}$, Small (0.3 to $2 \mathrm{~mm}$ diam.); L, large (1 to $8 \mathrm{~mm}$ diam.).

$\ddagger$ N.S.W., New South Wales, Australia; Tas., Tasmania, Australia.

all these isolates, except $\mathrm{S} 6$, when their sclerotia were incubated under field conditions during the Tasmanian autumn.

As ascospores were liberated from apothecia, they were collected on boiled cellophane sheets placed over water agar or nutrient agar media. Ascospores at different stages of development were studied, i.e. ascospores within asci, after discharge and at various stages of germination. Apothecia were cut into small pieces before fixation and staining.

The spores and hyphae on cellophane strips and the apothecial pieces were fixed in ethanol/acetic acid $(3: 1, v / v)$. With gentle handling, most of the materials remained on the cellophane throughout the fixing and staining processes. Several nuclear staining techniques were tried, including those which used acetocarmine, aceto-orcein, Feulgen reagent, iron alum haematoxylin and Giemsa. The Giemsa staining method (C.M.I., 1968) was the most reliable and was used to obtain the results presented below. After staining, the vegetative hyphae and ascospores, still on the cellophane strips, were mounted on microscope slides. Stained pieces of apothecia were teased apart before mounting. Chromosome numbers were counted at anaphase-telophase stages of mitotic division; nuclear numbers were determined in ascospores at the different developmental stages.

\section{RESULTS}

\section{General observations}

Except for the numbers of chromosomes and the numbers of nuclei in ascospores, the general cytological characteristics of the three Sclerotinia species were essentially similar. The vegetative hyphae were multinucleate; in hyphal tips the number of nuclei varied from two to several (Fig. 1 $a, b$ ), while in the older parts of main hyphae more than a hundred nuclei were sometimes observed (Fig. 1c). The sizes of nuclei in the older hyphae varied from small fragments consisting of a few chromosomes to some very large nuclei (Fig. 1d). The nuclei in young hyphae, hyphal tips, ascospores and germinating ascospores were of a constant size of about 1.5 to $2 \mu \mathrm{m}$ (Figs $1 a, b, 2,3,4$ ). Mitotic divisions were frequent and a characteristic feature in all isolates was' the synchronous mitotic 

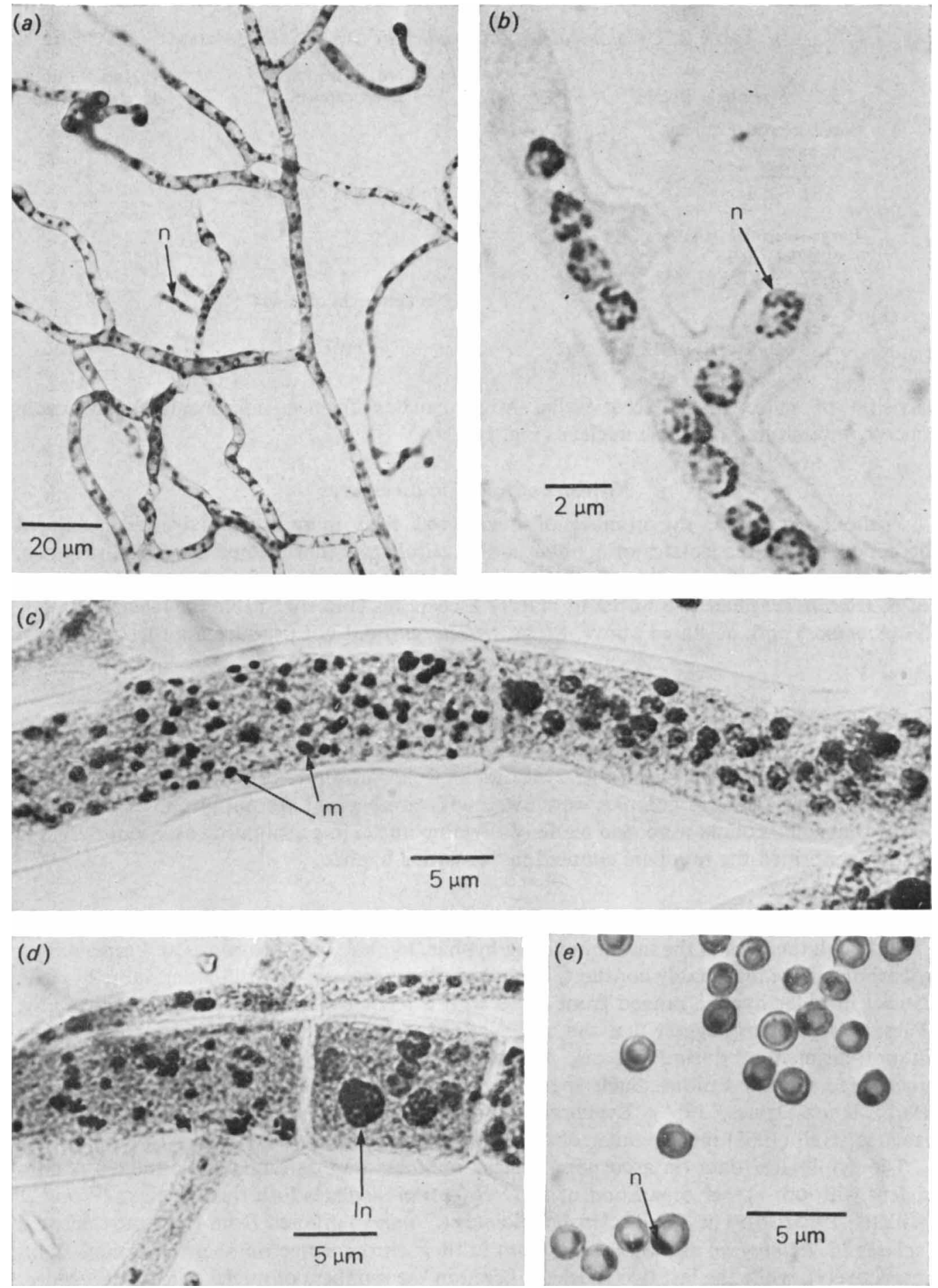

Fig. 1. General cytological characteristics of Sclerotinia species. (a) Vegetative mycelium of isolate S3 (S. minor) showing the multinucleate condition of hyphal cells (n, nucleus). (b) Nuclei at hyphal tips of isolate S8 (S. sclerotiorum). (c) Large main vegetative hypha of isolate S8 showing large numbers of nuclei; the cell on the left shows synchronous mitosis of nuclei (m, mitotic figures). (d) Different sizes of nuclei in a large hypha of isolate S8; note the large nuclei (ln). (e) Microconidia of isolate $\mathbf{S 7}$ (S. trifoliorum); each microconidium contains one nucleus. 
Table 2. Cytological characteristics of Sclerotinia isolates

\begin{tabular}{|c|c|c|}
\hline Sclerotinia isolate & $\begin{array}{l}\text { No. of nuclei } \\
\text { in ascospore }\end{array}$ & $\begin{array}{l}\text { Haploid no. } \\
\text { of chromosomes }\end{array}$ \\
\hline $\begin{array}{l}\text { Small-sclerotial isolates } \\
\text { S. minor } \\
\text { S3, S22, S77 } \\
\text { S1, S2, S4 }\end{array}$ & $\stackrel{4}{\text { No apothecia obtained }}$ & $\begin{array}{l}4 \\
4\end{array}$ \\
\hline $\begin{array}{l}\text { Large-sclerotial isolates } \\
\text { S. trifoliorum } \\
\text { S7, S33/1, S47, S48, S76 } \\
\text { S6 }\end{array}$ & $\begin{array}{c}4 \\
\text { No apothecia obtained }\end{array}$ & $\begin{array}{l}8 \\
8\end{array}$ \\
\hline $\begin{array}{l}\text { S. sclerotiorum } \\
\text { S8, S9, S10, S11, S12, S13, S92 }\end{array}$ & 2 & 8 \\
\hline
\end{tabular}

division of nuclei in adjacent cells. Most isolates formed microconidia and each microconidium had only one nucleus (Fig. 1e).

\section{Numbers of nuclei in ascospores}

Without exception, the number of nuclei was four in undischarged and discharged ascospores of all the isolates of $S$. minor and S. trifoliorum that formed apothecia (Figs $2 a$, $3 a$; Table 2). This number was present early in the differentiation of ascospores. All isolates of $S$. sclerotiorum had two nuclei in mature ascospores (Fig. $4 a$; Table 2). Isolates S1, S2, S4 (S. minor) and, as stated above, S6 (S. trifoliorum) did not produce apothecia.

\section{Chromosome numbers}

The haploid number of chromosomes of nuclei in hyphal tips at anaphase-telophase stages of mitosis was four for $S$. minor (Fig. $2 b$; Table 2) and eight for $S$. trifoliorum and $S$. sclerotiorum (Figs $3 b, 4 b$; Table 2). Counts of chromosomes of dividing nuclei in large hyphae in older parts of colonies were extremely variable and are not given.

Chromosome counts were also made of dividing nuclei in germinating ascospores. These results confirmed the numbers counted in vegetative hyphae.

\section{DISCUSSION}

Although the sizes of the nuclei in young hyphae, hyphal tips, ascospores and germinating ascospores were reasonably constant, great variations were observed in older, large hyphae. Nuclei in older hyphae ranged from those with a few chromosomes to those with many. These observations suggest that the nuclei of old vegetative hyphae are unstable, resulting in non-disjunction during mitosis, nuclear fragmentation, non-separation of daughter nuclei and nuclear fusions. Such aneuploidies have been reported in other fungi (Kafer, 1961; Knox-Davies, 1967). Synchronous mitotic divisions frequently occurred in all isolates; Hall (1963) made similar observations with Monilinia fructicola.

The cytological data on ascospore nuclear numbers and chromosome numbers is consistent with our earlier separation of these Sclerotinia isolates into three species (Wong \& Willetts, $1975 a, b)$. The small-sclerotial isolates $(S$. minor) differed from the large-sclerotial isolates ( $S$. trifoliorum and $S$. sclerotiorum) in their chromosome numbers (four and eight, respectively), while the last two species differed in the numbers of nuclei in their ascospores (four and two, respectively). Our results confirm those of Björling $(1942,1951)$ on the numbers of nuclei in ascospores of $S$. trifoliorum and $S$. sclerotiorum, but our haploid chromosome count of eight for both species is contrary to his count of six chromosomes. However, our findings agree with those of Frandsen (1946) who concluded that S. trifoliorum has a haploid chromosome number of eight. 
Fig. 2
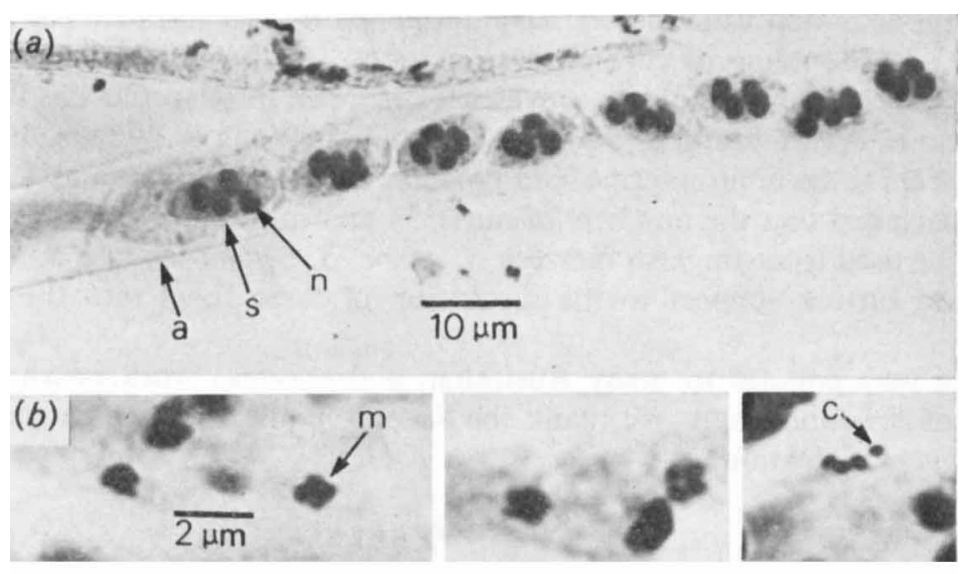

Fig. 3
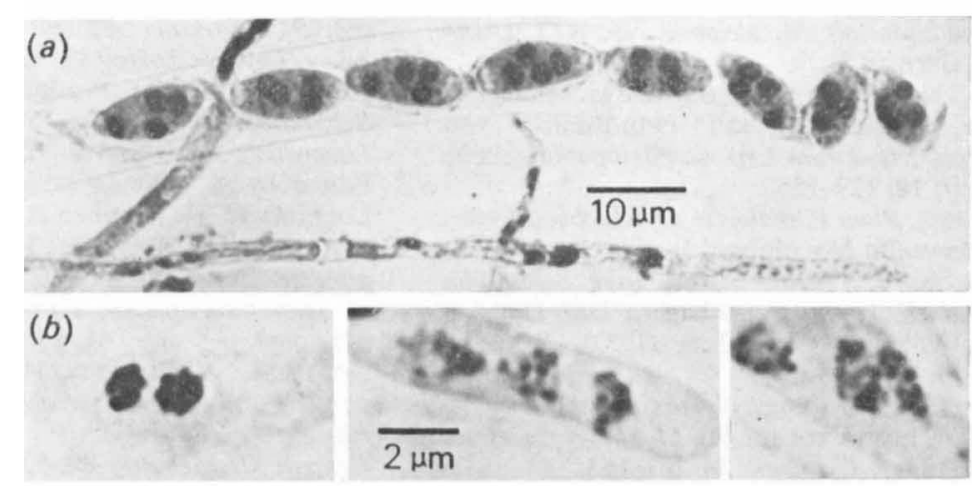

Fig. 4
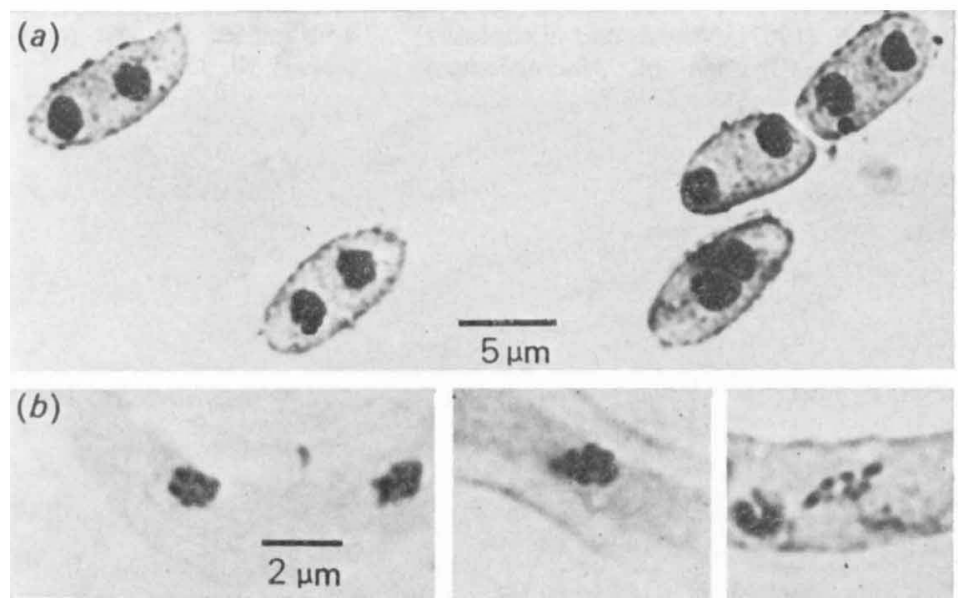

Figs 2 to 4. Ascospore nuclear numbers and chromosome numbers of Sclerotinia species.

Fig. 2. Small-sclerotial isolate S3 (S. minor). (a) Ascospores (s) in ascus (a); each spore has four nuclei $(\mathrm{n})$. (b) Chromosomes at anaphase-telophase stages of mitosis; note the four-chromosome condition of the daughter nuclei ( $\mathrm{m}$, mitotic figure; $\mathrm{c}$, chromosome).

Fig. 3. Large-sclerotial isolate S48 (S. trifoliorum). (a) Ascospores in ascus, each with four nuclei. (b) Eight-chromosome condition of daughter nuclei at anaphase-telophase stages of mitosis. Fig. 4. Large-sclerotial isolate S8 (S. sclerotiorum). (a) Discharged ascospores, each with two nuclei. (b) Eight-chromosome condition of daughter nuclei at anaphase-telophase stages of mitosis. 
The large-sclerotial isolates may have developed from a form similar to the present-day $S$. minor by a doubling of chromosome numbers. Such polyploidization would result in changes in form and physiology, of which an increase in sclerotial size could be one of the most obvious. As we found in our previous studies (Wong \& Willetts, 1975a, b), S. trifoliorum appears to be in an intermediate position between $S$. minor and $S$. sclerotiorum.

It is concluded that the numbers of nuclei in ascospores and haploid chromosome numbers can be used to distinguish between $S$. minor, $S$. trifoliorum and $S$. sclerotiorum. These results add further support to the separation of these fungi into three distinct species.

We are very grateful to many Australian and overseas workers who supplied us with cultures of Sclerotinia spp. We thank the Reserve Bank of Australia for financial support during this investigation.

\section{REFERENCES}

BJörLING, K. (1942). Undersoleningar Rorande Klovetrotan II. Studier av utvecklinghistoria och variation hos Sclerotinia trifoliorum. Staten Vaxtskyddasanstalt Meddelande No. R37. (Abstract in German.)

BuörliNG, K. (1951). Ưber die Entwickelungsgeschichte, Variabilität und Pathogenität von Sclerotinia trifoliorum Erikss. Phytopathologische Zeitschrift 18, 129-156.

C. M. I. (1968). Plant Pathologist's Pocketbook. Kew: Commonwealth Mycological Institute.

FrandSEN, K. J. (1946). Studier over Sclerotinia trifoliorum Eriksson. Copenhagen: Def. DanskeForlag. [Cited in Olive, L.S. (1953). Botanical Review 19, 439-578.]

Hall, R. (1963). Cytology of asexual stages of the Australian brown rot fungus Monilinia fructicola (Wint.) Honey. Cytologia 28, 181-193.

KAFER, E. (1961). The processes of spontaneous recombination in vegetative nuclei of Aspergillus nidulans. Genetics 46, 1581-1609.

KNOx-D.4VIES, P. S. (1967). Mitosis and aneuploidy in the vegetative hyphae of Macrophomina phaseoli. American Journal of Botany 54, 1290 1295.

Purdy, L. H. (1955). A broader concept of the species Sclerotinia sclerotiorum based on variability. Phytopathology 45, 421-427.

Purdy, L. H. (1967). Production of apothecia by Sclerotinia sclerotiorum. In Source-book of Laboratory Exercises in Plant Pathology, p. 41. Edited by A. Kelman et al. San Francisco and London: W. H. Freeman \& Co.

WonG, A.-L. \& Willetts, H. J. (1973). Electrophoretic studies of soluble proteins and enzymes of Sclerotinia species. Transactions of the British Mycological Society 61, 167-178.

Wong, A.-L. \& Willetts, H. J. (1975a). A taxonomic study of Sclerotinia sclerotiorum and related species: mycelial interaction. Journal of General Microbiology 88, 339-344.

Wong, A.-L. \& Willetts, H. J. (1975b). Electrophoretic studies of Australasian, North American and European isolates of Sclerotinia sclerotiorum and related species. Journal of General Microbiology 90, 355-359. 